\title{
Bromélias no Paisagismo, Saúde Pública e Ambiente
}

Marcelo Guena de Oliveira

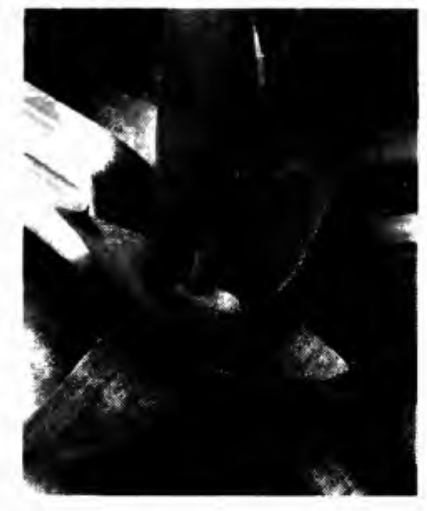

Biólogo, mestre pela Universidade de São Paulo, sócio-gerente da Botãnica Paisagismo, São Paulo-SP

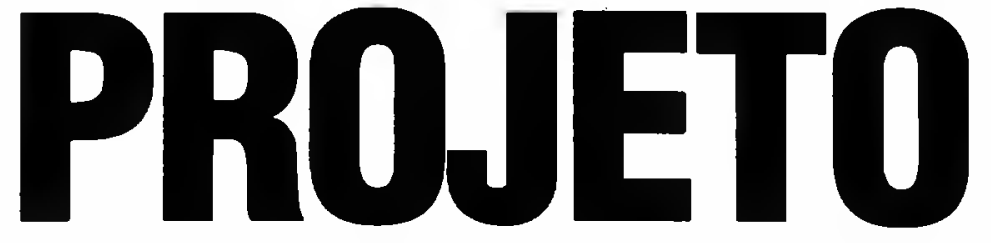




\section{Bromélias no Paisagismo, Saúde Pública e Ambiente}

\section{INTRODUçÃo}

Quando se usa determinada espécie de planta em um jardim, contribui-se para construir um ambiente urbano específico. Alguns dos objetivos principais nessa construção seriam garantir uma existência humana saudável e um ambiente sustentável. Para atingir tais objetivos é fundamental considerar como funciona o ecossistema urbano e qual o papel de seus componentes, inclusive a vegetação (Spirn, 1984; Lyle, 1985). No Brasil, uma abordagem próxima, o desenho da paisagem, tem sido preconizada por Franco, 1997

Entretanto, conforme será demonstrado, o uso de algumas espécies de bromélias para fins ornamentais em jardins brasileiros tem sido incoerente com as abordagens levantadas, ou seja, alguns projetos paisagísticos podem não estar contribuindo para atingirmos uma vida mais saudável e um ambiente sustentável. Esse problema pode se agravar, já que houve um grande aumento do consumo dessas plantas em relação a outras plantas ornamentais, principalmente no ano de 1999 (Godas, 1999). Nesse contexto, dois pontos sobre o uso de bromélias merecem discussão:

- a hipótese de que o uso de certas espécies de bromélias nos jardins de algumas cidades brasileiras pode contribuir na propagação de doenças humanas;

- parte das bromélias comercializadas livremente provém de extrativismo ilegal e danoso aos ecossistemas naturais.

\section{Bromélias, Mosouitos e Doenças}

\section{As bromélias}

Existem aproximadamente 3 mil espécies de bromélias (família Bromeliaceae), incluindo dezenas de híbridos. Uma destas é nativa da África e as restantes das Américas, principalmente das regiões tropicais. No território brasileiro encontram-se mais de 1.500 espécies, sendo especialmente diversas e abundantes nos domínios da Mata Atlântica (Leme, 1993). No estado de Santa Catarina, por exemplo, em determinadas regiões preservadas da Mata Atlântica, foram encontradas entre 6 a 13 bromélias $/ m^{2}$ (Reitz, 1983); ou, ainda, mil destas plantas crescendo sobre uma única árvore (Veloso et al, 1956a). Também no estado de São Paulo as bromélias são abundantes (Foto 1) e diversas, especialmente na restinga (Mantovani, 1992), um dos ecossistemas litorâneos da Mata Atlântica. 


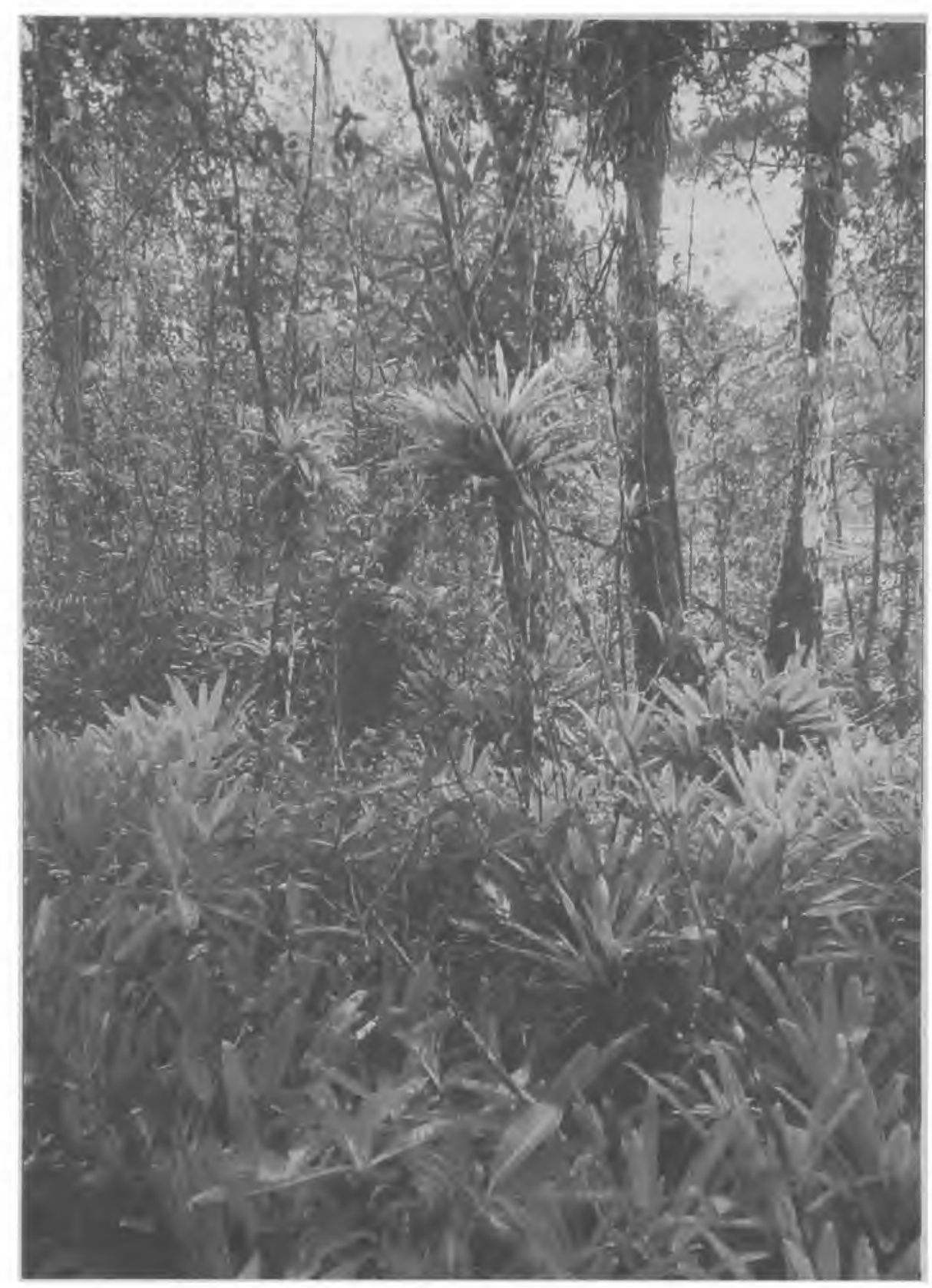

Foto 1: Floresta de restinga, em Itanhaem-SP, apresentando grande densidade de bromélias, principalmente no solo Fonte: Foto do autor

Onde a mata original foi destruída, como na maior parte da cidade de São Paulo, encontra-se pouquíssimas bromélias espontâneas; Aechmea bromeliifolia é um exemplo (Foto 2). Esta espécie pode ser encontrada em árvores muito usadas na arborização de ruas, como sibipiruna (Caesalpinia peltophoroides, Legumino-sae) ou tipuana (Tipuana tipu, Leguminosae). A grande maioria das outras espécies encontradas em jardins são cultivadas; é comum encontrarse A/cantarea imperialis (Fotos 3 e 4), Vriesia bituminosa, V. gigantea e V. hieroglyphica (Foto 5) e Neoregelia sp (Foto 6) plantadas no solo. A primeira espécie, por ser a maior e mais freqüentemente usada, pode ser considerada mais importante nos jardins dessa cidade. 


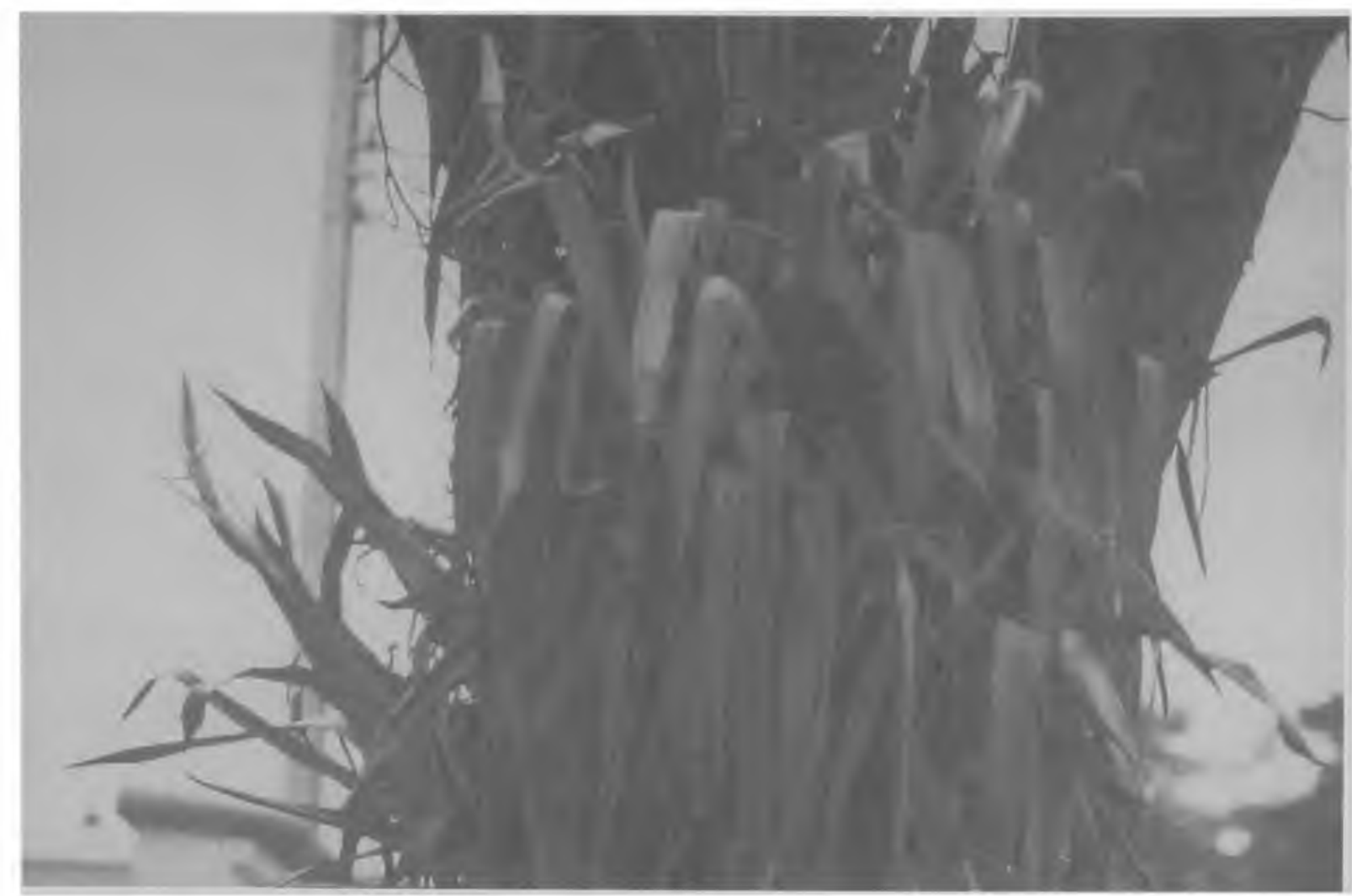

Foto 2: Aechmea bromeliifolia sobre tronco de sibipiruna (Caesalpinia peltophoroides), uma das árvores mais comuns nas ruas de São Paulo-sP Fonte: Foto do autor

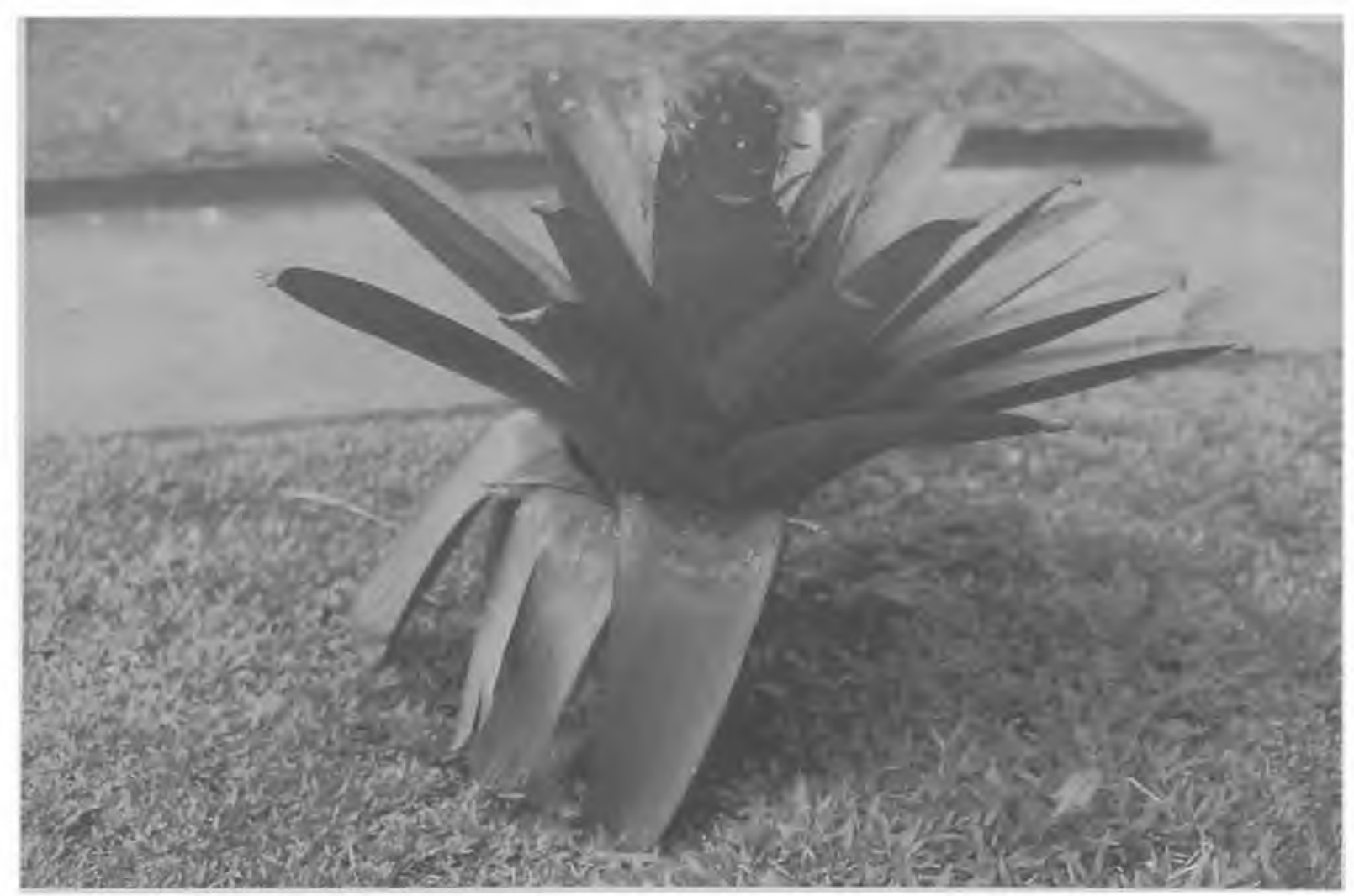

Fotos 3: Bromélias comuns em jardins de algumas cidades do estado de São Paulo 3a: (A. imperialis)

Fonte: Foto do autor 
Marcelo Guena de Oliveira

Fotos 3b: V. hieroglyphica Fonte: foto do autor

Fotos 3c: $V$. bituminosa Fonte: foto do autor
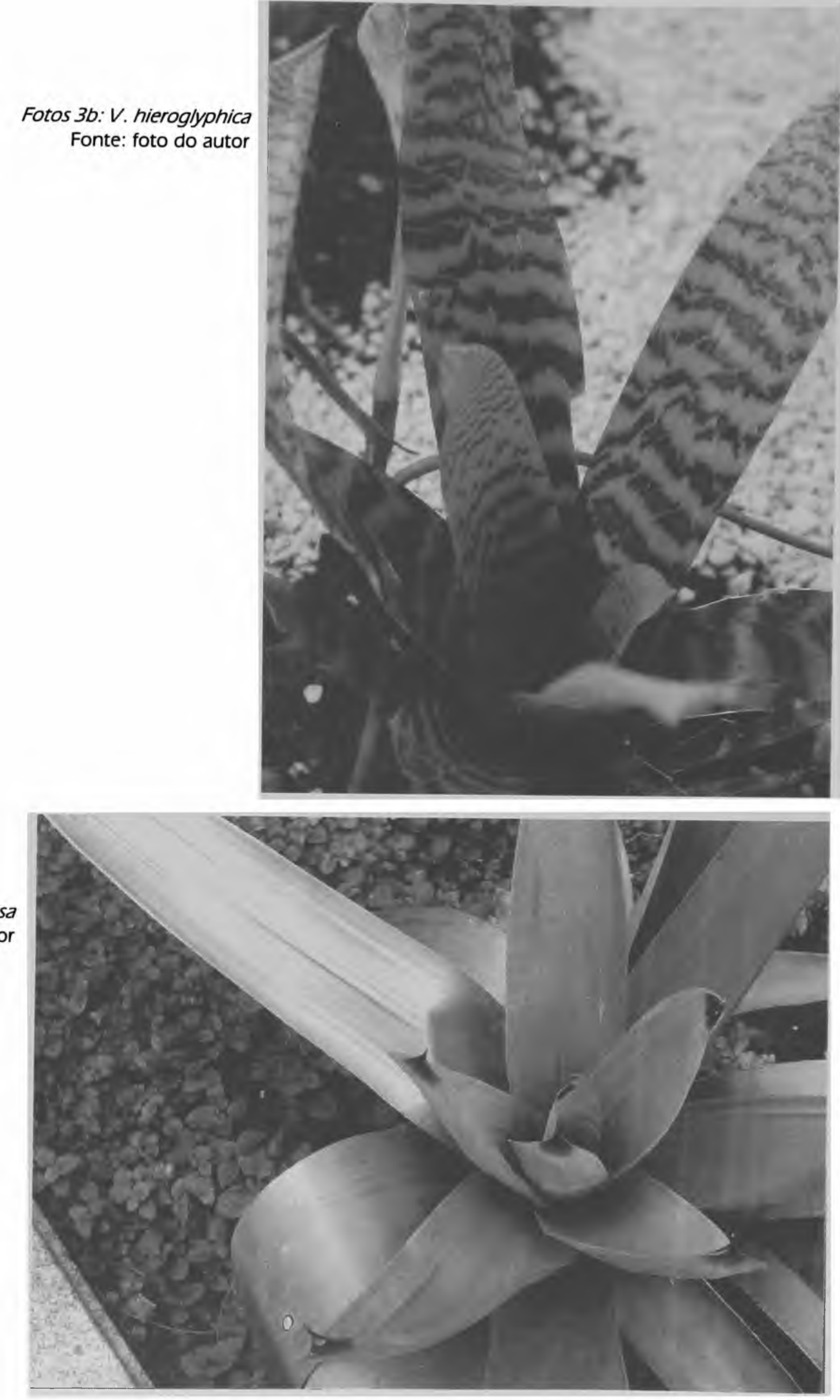


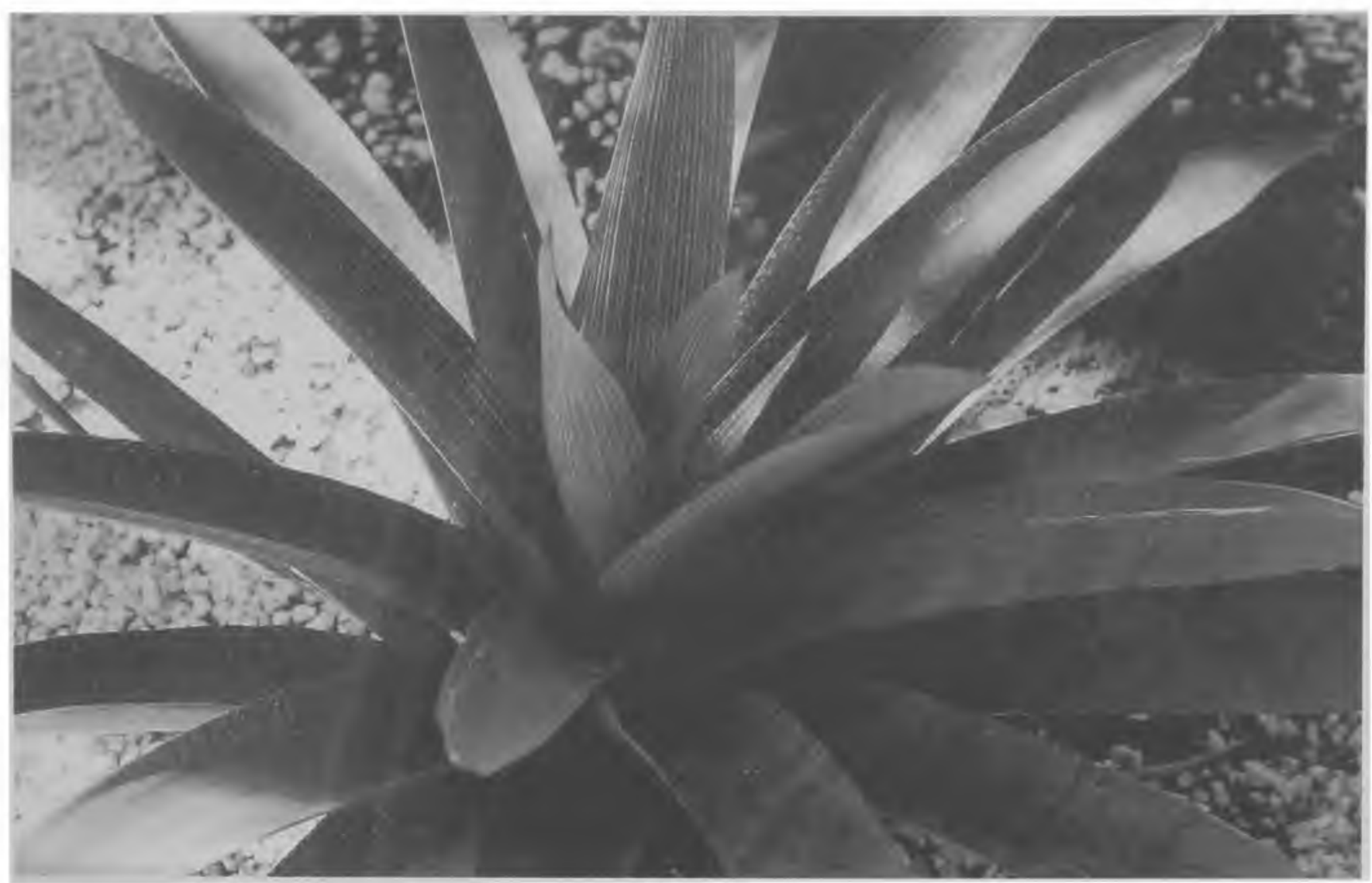

Fotos 3c: $V$. gigantea

Fonte: foto do autor

Muitas bromélias possuem formas e cores raras em outras plantas, o que as tornam especiais para o uso ornamental. Durante o século 19 os europeus importaram muitas bromélias para esse fim (Dean, 1995). Mas foi durante a segunda metade deste século que se iniciou mais intensamente o uso de bromélias em jardins brasileiros, uso este influenciado pelo trabalho pioneiro do paisagista Roberto Burle Marx. O jardim do Banco Safra, na rua da Consolação, em São Paulo-SP, exemplifica o uso dessas plantas pelo paisagista (Motta, F. L. 1983). Além desse uso ornamental recente, empregam-se, há séculos, certas espécies para fins medicinais, religiosos, alimentares, em cercas vivas ou, ainda, na produção de fibras para cordas e linhas (Rios \& Khan, 1998).

Algumas espécies de bromélias absorvem a água e os minerais necessários para seu desenvolvimento pelas raízes infiltradas no solo, como o abacaxi, Anannas comosus. Outras espécies absorvem os nutrientes pelas folhas, diretamente de pequenas partículas suspensas no ar, como muitas espécies de Tillandsia. Um terceiro grupo de bromélias absorve os nutrientes da água acumulada entre as folhas; estas, dispostas em roseta, formam um receptáculo que acumula as águas das chuvas e orvalho (Fotos 4 e 5). Essas plantas são chamadas de broméliascisternas (Reitz, 1983). Indivíduos de $V$. gigantea, quando adultos, podem conter até 4 litros de água (Reitz, 1983) e em casos extremos, como de $A$. imperialis, até 30 litros.

É nas bromélias-cisternas, com muitas espécies ornamentais, que será centrada a discussão. Essas plantas possuem raízes, cuja função principal é fixar o indivíduo no substrato. Junto com a água, entre as folhas, acumulam-se detritos vegetais e animais, criando um ambiente ideal 
para a multiplicação de várias espécies de animais, inclusive larvas de mosquitos /o ciclo de vida destes é explicado resumidamente no próximo item deste artigol. A seguir citam-se alguns exemplos da associação entre bromélias e mosquitos, salientando que alguns destes são vetores de doenças humanas.

Lutz, 1950, em seus estudos sobre malária no início do século, encontrou 40 espécies de mosquitos na Mata Atlântica, em Santos. Oito destes mosquitos criavam-se em bromélias, entre eles Anopheles (Kerteszia) cruzii, espécie então incriminada como vetor de malária. Posteriormente, descobriu-se que todas as espécies do subgênero Kerteszia são vetores da malária e criam-se em bromélias (Veloso, 1958). Reitz, 1983, forneceu uma lista de bromélias que servem de criadouro para esses mosquitos, entre elas estão $A$. bromeliifolia e $V$. gigantea. As bromélias também são criadouros freqüentes de espécies do gênero Culex, subgênero Melanoconion e Microculex (Consoli et al, 1994). Outras espécies, como Culex quinquefasciatus, espécie comum em São Paulo, usam-nas esporadicamente (Forattini, 1965a). Já no início do século, no Rio de Janeiro, encontraram-se em bromélias larvas de Aedes aegypti, vetor da dengue e febre amarela (Kumm, 1933). O abacaxi, apesar de nāo ser uma bromélia-cisterna típica, também se mostrou criadouro de mosquitos. Essa planta, usada também como ornamental, foi considerada uma das espécies mais importantes como criadouro de Ae. aegypti

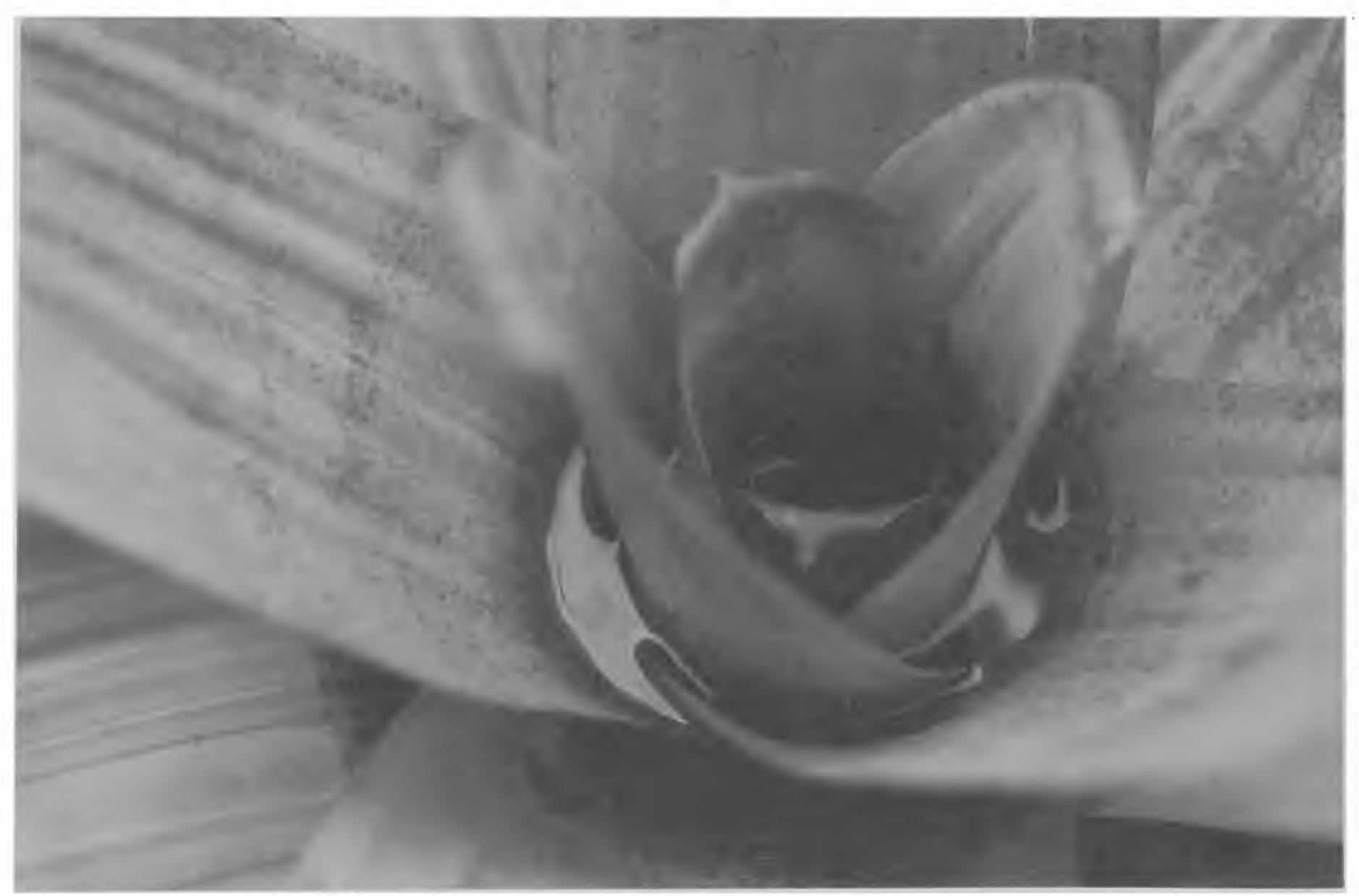

Foto 4: Água acumulada em Alcantarea imperialis em jardim, em São Paulo-SP Fonte: Foto do autor 


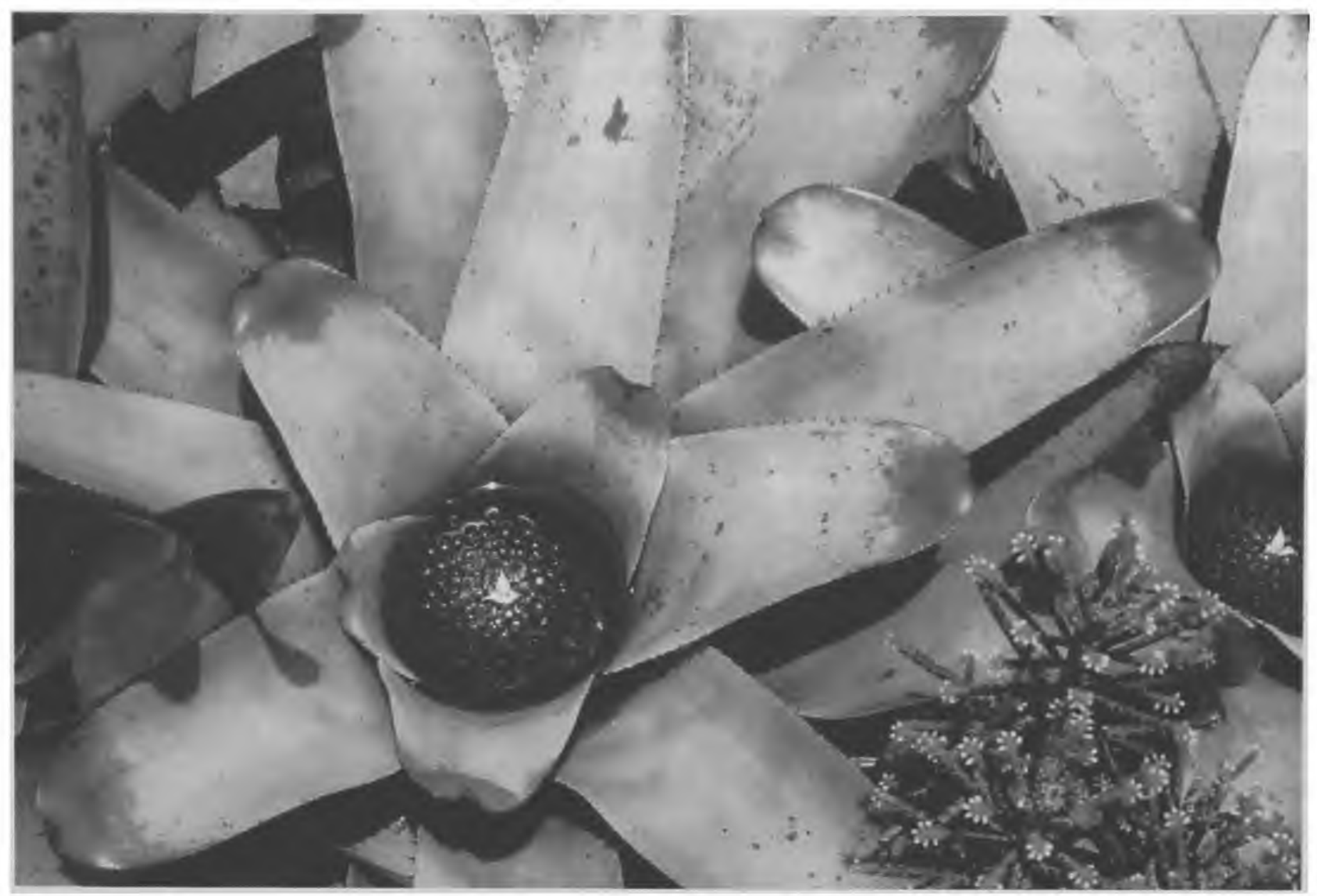

Foto 5: Água acumulada em Neoregelia sp em jardim, em São Paulo-sP Fonte: Foto do autor

em alguns locais da África (Haddow, 1948); é também criadouro de An. cruzii (Reitz, 1983). Recentemente, foi registrado no estado de São Paulo Ae. albopictus, também vetor da dengue e febre amarela, introduzido da Ásia (Forattini, 1986). Foi encontrado em bromélias, como em outros recipientes, na periferia da cidade de São Paulo (Natal, 1997), em ambiente urbano na Vila de Pedrinhas, Ilha Comprida-SP e ambiente silvestre em Ilha Bela - SP (Forattini et al, 1998b). Em determinados locais, por exemplo Jacarepaguá-RJ, as bromélias-cisternas foram apontadas como o principal tipo de criadouro natural' de mosquitos (Lourenço de Oliveira et al, 1986). Em vários municípios do estado de São Paulo, tais como Piracicaba e São Sebastiāo, tem-se observado larvas de mosquitos, principalmente de $A$. imperialis plantada em jardins. Portanto, as bromélias-cisternas são importantes criadouros naturais de mosquitos, sendo sua redução indicada como método prático de controlar a população de certos mosquitos (Frank, 1996).

(1) Segundo Forattini, 1962, os criadouros de mosquitos podem ser "artificiais" (pneus e frascos de plástico, por exemplo) ou "naturais", estes últimos podem ser divididos como de "solo" (lagoas; remansos e pequenas depressões no solo, por exemplol ou de "recipientes" que por sua vez podem ser "transitórios" (folhas cạídas, por exemplo) ou "permartentes" ou semi-permanentes como as bromélias-cisternas e ocos de árvores: 
Entretanto, a simples capacidade de armazenar água não torna determinada espécie de bromélia um bom criadouro. As larvas de An. cruzii, por exemplo, podem ser encontradas em plantas com capacidade de armazenar $5 \mathrm{ml}$ ou mais de água (Veloso et al, 1956b), contudo é mais freqüente encontrá-las quando esse valor ultrapassa 1 litro (Forattini, 1962). Veloso et al, 1956a, demonstrou que as bromélias-cisternas, com maior capacidade de armazenar água, como $V$. gigantea, e população mais densa, formam melhores criadouros de mosquitos do que bromélias sem essas características.

\section{Os mosquitos: ciclo de vida e doenças transmitidas}

Existem aproximadamente 3.600 espécies de mosquitos (insetos, Díptera, Culicidae) espalhados pelo mundo (Crosskey, 1988). Todas as espécies passam parte do seu ciclo de vida, larva e pupa, na água (Figura 6).

Esta água pode ser, por exemplo, de um rio, lago, represa, caixa d'água, piscina, vasilhames de diversos tipos, pequenas depressões no solo, cavidades nas rochas e troncos e, como já ressaltado, em várias espécies de bromélias.

As espécies de mosquitos variam quanto à escolha do local para criação das larvas. Aquelas do gênero Mansonia, por exemplo, procriam na presença de plantas aquáticas (Forattini, 1965b), outras, como já exemplificado, preferencialmente em bromélias, e An. Darlingi, em grandes corpos de água (Consoli et al, 1994).

Também há espécies que preferem o ambiente urbano, como Culex quinquefasciatus (Foto 7) e Ae. aegypti. A primeira espécie é um dos mosquitos mais comuns nas áreas urbanas e cria-se em vários tipos de reservatórios de águas (Forattini, 1965a). Outros mosquitos preferem o ambiente silvestre e há ainda aqueles que ocupam ambos os ambientes, como Ae. albopictus (Foto 8) (Estrada-Franco, 1995).

Muitas espécies de mosquitos podem transmitir doenças aos humanos, cães, gatos e vários outros animais. C. quinquefasciatus é vetor da filariose humana (Forattini, 1965b), filariose de animais domésticos (cachorro e gato) (Labarthe et al, 1998) e alguns vírus como o Oropouche no Pará (Consoli et al, 1994). An. cruziié o principal vetor bromelícola de malária endêmica no Sul e Sudeste do Brasil (Veloso, 1958). Ae. aegyptie Ae. albopictus transmitem a dengue, a febre amarela e outras viroses (Forattini, 1965a, 1965b, Estrada-Franco, 1995). A última espécie, por estar progressivamente ocupando tanto regiōes urbanas como silvestres, torna-se séria ameaça à saúde pública no Brasil. Há o risco desse mosquito infectar os habitantes urbanos com doenças do ambiente silvestre, como a febre amarela silvestre, tornando esta doença urbana (Forattini et al, 1998; Gomes, A. C. et al, 1999).

Infelizmente não se têm vacinas ou remédios eficientes para todas essas doenças. Até o momento, não há métodos que evitem as picadas dos mosquitos em todas as situações e os 
que existem nāo estāo disponíveis a toda população humana. Portanto, o controle das populaçōes desses insetos torna-se necessário. Entre os meios usados na profilaxia das doenças levantadas estão as medidas contra as formas imaturas dos mosquitos ou métodos antilarvários (Forattini, 1962). Por isso a importância de saber se as bromélias urbanas são criadouros desses insetos.

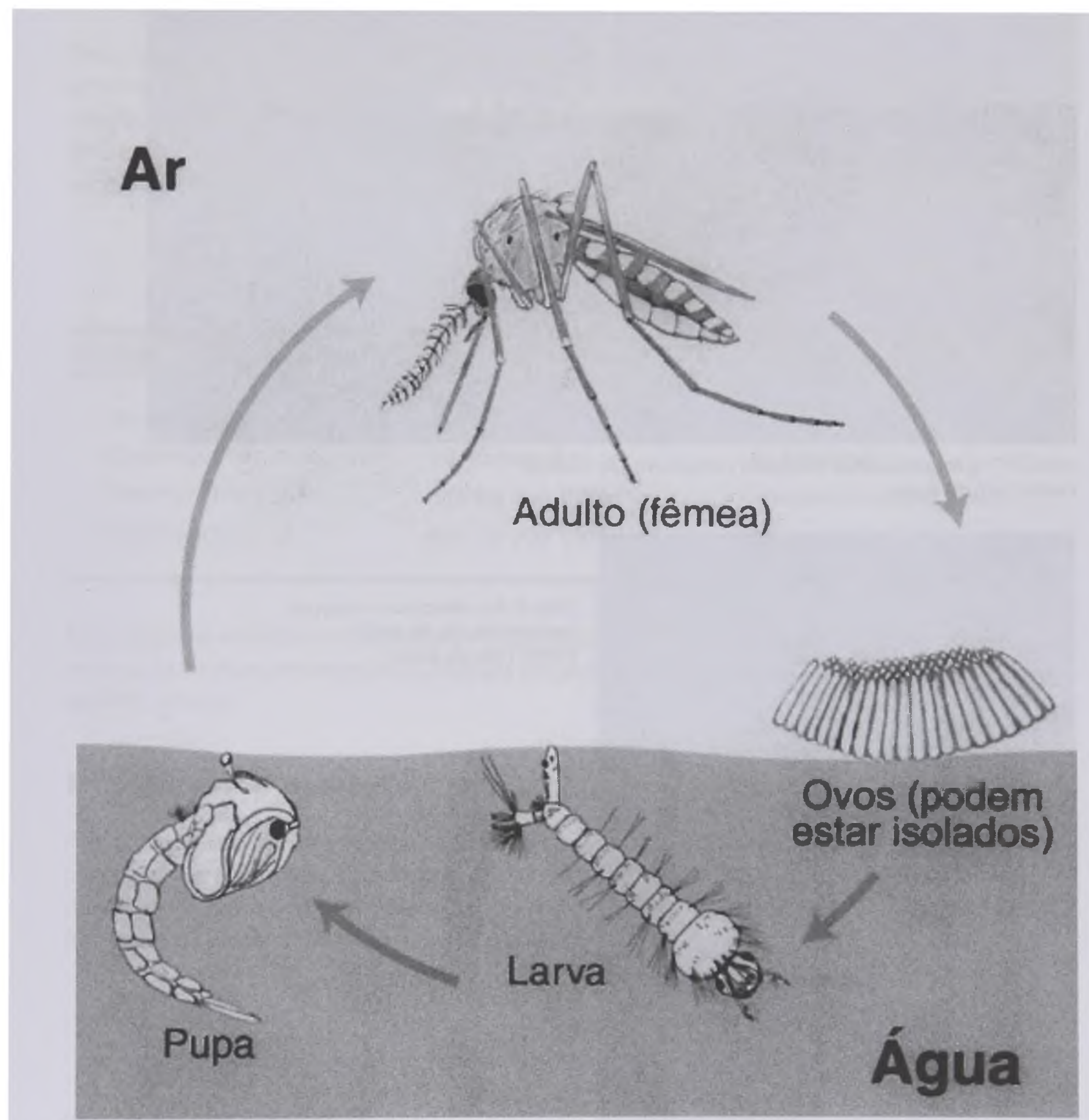

Figura 6: Ciclo de vida de um mosquito

Fonte: autor

São Paulo n. 13 p. 73 - 95 - dez. 2000 


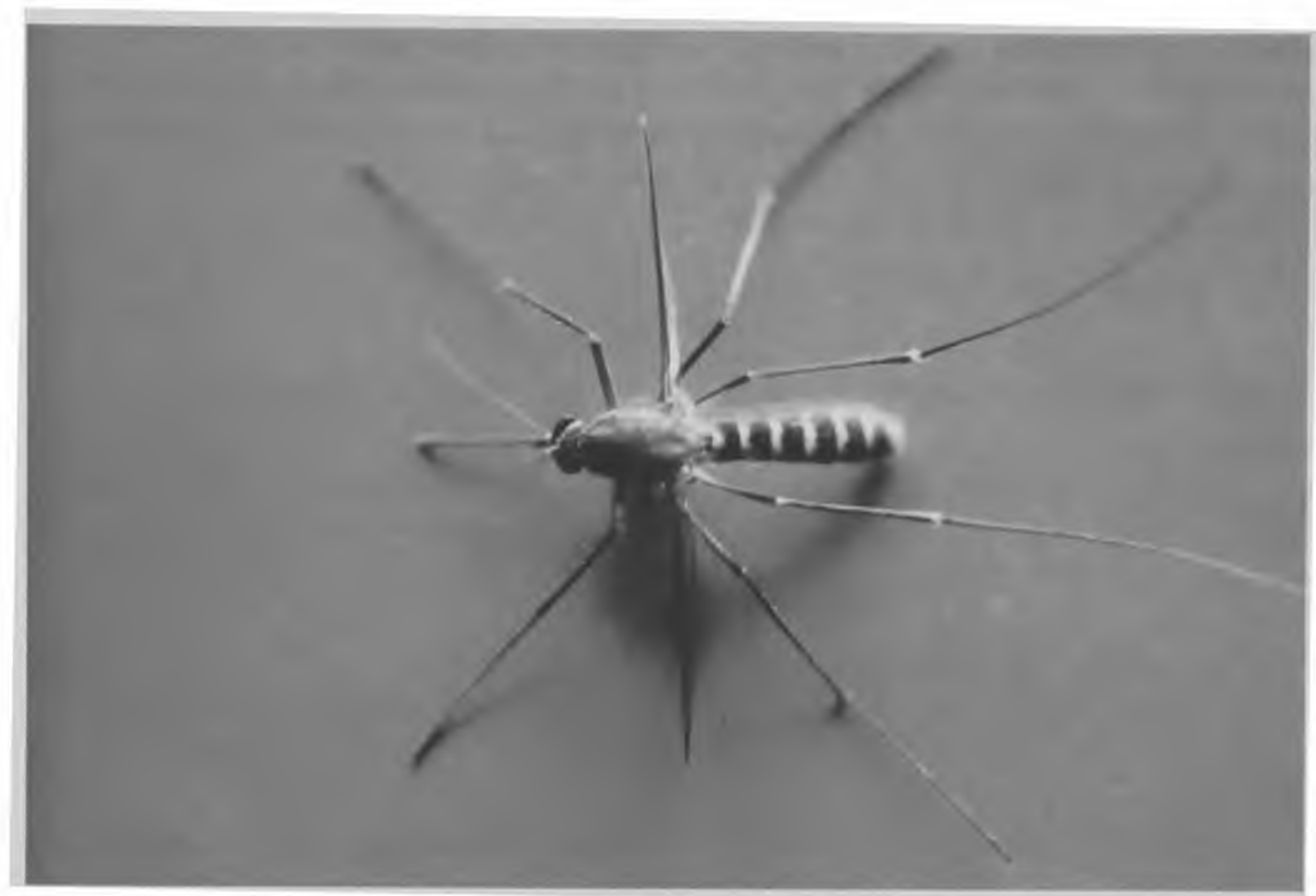

Foto 7: C. quinquefasciatus, mosquito comum em São Paulo-SP Fonte: Foto do autor

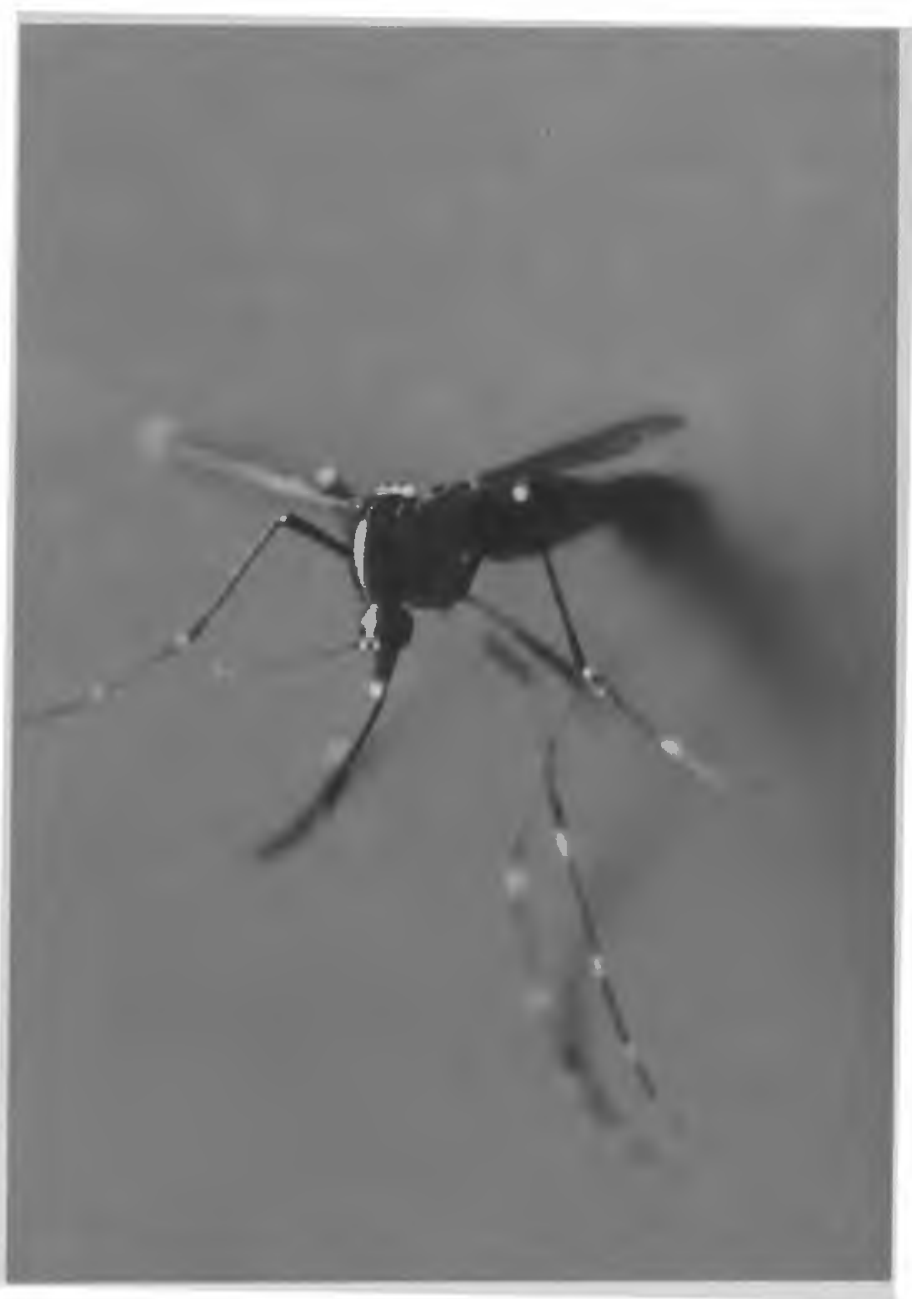

Foto 8: Ae. albopictus, mosquito

comum em São Paulo-SP

Fonte: Foto do autor

\section{Paisagem} Ambiente

Ensaios

13 


\section{Bromēlias e mosquitos no ambiente urbano}

Como citado acima, Ae. albopictus foi encontrado em bromélias na periferia da cidade de São Paulo. Suspeitou-se de que esta e outras espécies ocorressem também em bromélias nas partes mais centrais de um núcleo urbano como São Paulo, apesar das diferenças ambientais entre essas áreas e a periferia (Sobral, 1996).

Para confirmar essa suspeita realizaram-se algumas coletas preliminares em bromélias ornamentais dessa cidade, entre março e abril de 1999. As áreas de coleta foram escolhidas pela facilidade de acesso. Os resultados dessas coletas estāo na Tabela 1. Encontraram-se larvas de mosquitos, inclusive Ae. albopictus, em diferentes tipos de bromélias, algumas destas se encontravam em jardins localizados em ambiente de intenso tráfego de automóveis.

Tabela 1 Larvas de mosquitos encontradas' em bromélias usadas em jardins da cidade de São Paulo-SP

\begin{tabular}{lll}
\hline Espécie & Local & Bromélia \\
\hline Ae. albopictus & Morumbi & A. Imperialis \\
C. quinquefasciatus & Vila Gertrudes & A. imperialis \\
Toxorhynchites sp & Alto da Boa Vista & Nidularium Billbergioides \\
Toxorhynchites sp & Alto da Boa Vista & Neoegelia sp \\
\hline
\end{tabular}

Essa pequena amostra inicial indica a necessidade de mais estudos para se entender a relação entre as bromélias ornamentais cultivadas em jardins e nos mosquitos vetores de doenças em regiōes urbanas.

\section{Bromélias e malária}

Até o momento mostraram-se evidências de que as bromélias-cisternas são importantes criadouros de mosquitos, que alguns destes são vetores de doenças humanas e se reproduzem nessas plantas também no meio urbano. Então a presença de bromélias contribuiria para a existência de determinadas doenças humanas?

(2) Coletadas pelo autor e determinadas por FERNANDES, A. (Faculdade de Saúde Pública da Universidade de São Paulol.

(3) Os mosquitos do gênero Toxorhynchites não sāo hematófagos, portanto não transmitem doenças para humanos (FORATTINI, 1965b). 
Para responder essa pergunta poder-se-ia retirar as bromélias de uma cidade, ou outro ambiente, com alta incidência de determinada doença e verificar o que aconteceria com a saúde pública local. Essa experiência, de forma parecida, já foi realizada, empregando-se três métodos: remoção manual de bromélias, aplicação de herbicidas e desmatamento. Os muitos casos de malária silvestre e urbana em Florianópolis-SC praticamente deixaram de existir após a destruição manual de 25 milhōes de bromélias-cisternas realizada até 1947 (Pinotti, 1949). Fora do Brasil também se realizaram experiências semelhantes. Na llha de Trinidad, por exemplo, a destruição de bromélias existentes no meio de plantações de cacau, pelo uso de herbicidas específicos, resultou em sucesso no combate à malária (Pittendrigh, 1946). Em certas regiōes, entretanto, devido aos custos e dificuldades técnicas desses dois métodos, empregou-se o desmatamento como forma de acabar com as bromélias, criadouros de mosquitos. O desmatamento também teve o objetivo de dificultar o acesso desses mosquitos já adultos aos centros urbanos. Em alguns municípios como Brusque, Blumenau e Joinville (SC), essa prática proporcionou resultados excelentes (Ferreira et al, 1951). Segundo Reitz, 1985, a destruição de milhões de bromélias e outros milhões de metros quadrados de florestas foi a única forma de proteger a saúde dos habitantes dos municípios dos estados de Santa Catarina, Rio Grande do Sul e Paraná, atingidos pela malária-bromélia. Em 1941, esta đoença atingia entre 30 a $40 \%$ da população do litoral de Santa Catarina.

Entretanto, sabe-se que o desmatamento deve ser evitado, pois gera muitos problemas ambientais, como a erosão dos solos, assoreamento de rios e represas e perda da biodiversidade. Mesmo assim a ocupação agrícola ou urbana dos ecossistemas naturais no Brasil foi feita destruindo-se, por vários motivos, as matas (Dean, 1995) e com elas provavelmente milhões de bromélias. Talvez o único ganho com essa destruição tenha sido a eliminação desses criadouros de mosquitos. Mas com esta ocupação surgiram uma série de problemas ambientais, como novos focos de criação de mosquitos em águas poluídas e paradas ou acumuladas nos diversos tipos de recipientes descartáveis (Forattini et al, 1998a), como latas, garrafas plásticas e pneus usados. Repor bromélias-cisternas no meio urbano seria aumentar ainda mais esses focos de criação. Também, como se discute a seguir, o uso descuidado dessas plantas pode aumentar os riscos de introdução de mosquitos e variedades destes onde nunca existiram ou onde foram erradicados.

\section{Bromélias ornamentais e a dispersão de mosquitos}

Segundo O'Meara et al, 1993, o uso ornamental de bromélias tem contribuído para a dispersão de Ae. albopictus na Flórida (EUA). Provavelmente o que está ocorrendo na Flórida ocorre no Brasil. Na Companhia de Entrepostos e Armazéns Gerais do Estado de São Paulo (Ceagesp), na cidade de São Paulo, local de maior comércio de plantas ornamentais do país, observaram-se lanvas de mosquito em mudas cariocas de $A$. imperialis. Nessas mesmas mudas não poderiam estar, também, centenas de ovos milimétricos de mosquitos? Sabe-se que em algumas espécies, como Ae. aegypti, a fase de ovo pode durar mais de um ano (Consoli \& LourençoOliveira, 1993). Provavelmente os comerciantes e produtores não receberam instruções 
quanto ao manejo adequado dessas plantas. Parte das plantas comercializadas provêm de produtores que possuem suas matrizes e as multiplicam por meio de sementes ou reprodução vegetativa. Outros, como discutido adiante, obtêm suas mudas retirando-as diretamente das matas. Em ambos casos as bromélias podem estar "contaminadas" com várias espécies de mosquitos.

\section{Deduções}

Resumindo, as bromélias-cisternas são importantes criadouros de mosquitos e, atualmente, parte destas bromélias são deslocadas em decorrência de seu comércio. Com estas propriedades, várias bromélias transformaram-se em potencial dizimador de mosquitos. Alguns destes mosquitos, encontrados em diversas partes do Brasil, são vetores de doenças humanas e de animais domésticos. As afirmaçōes acima parecem serem válidas tanto para o ambiente silvestre quanto para o rural ou para o urbano. Pode-se deduzir, então, que quanto mais bromélias forem usadas em jardins brasileiros, maior será o risco de se aumentarem a quantidade $e$ os tipos de mosquitos e doenças por eles transmitidas na região urbana. Entretanto, esta dedução necessita confirmação experimental, já que as melhores demonstrações existentes provêm da retirada de bromélias não-cultivadas no Sul do Brasil.

O plantio de bromélias-cisternas engrossa a lista de criadouros de mosquitos em áreas urbanas. Assim, este plantio intenso aumentará a freqüência de um nicho atualmente pouco comum em muitos ecossistemas urbanos brasileiros. O retorno deste nicho ou a inclusão deste pode facilitar o surgimento de mosquitos vetores emergentes (Forattini, 1999). Isto pode ter implicações graves em regiōes como São Paulo, no qual se sabe existir Ae. aegyptie Ae. albopictus, além de ser área natural de $A$. cruzii (Aragão, 1964) e outros mosquitos.

O uso de bromélias e a forma de obtê-las resgata o segundo ponto de discussão deste artigo.

\section{Extrativismo de Bromélias}

Tem-se notícia do extrativismo de plantas ornamentais da Mata Atlântica, em escala comercial, desde o século 19. Esse extrativismo, que destruía muitas das populações das espécies coletadas, visava atender principalmente o mercado europeu e era realizado por firmas especializadas na coleta de bromélias, cactos e orquídeas. Neste século, até a década de 70, "os vendedores de orquídeas e bromélias enchiam furgões de flores, a maioria em parques e outras reservas, para vendê-las nas cidades" (Dean, 1995).

Atualmente, parte das bromélias encontradas em feiras, floriculturas, empresas de paisagismo e jardins provêm de viveiros devidamente regulamentados. A procedência dessas bromélias evidencia-se pelo excelente estado de conservação das folhas e flores, por muitas serem espécies exóticas ou híbridas e algumas terem a marca do produtor. 


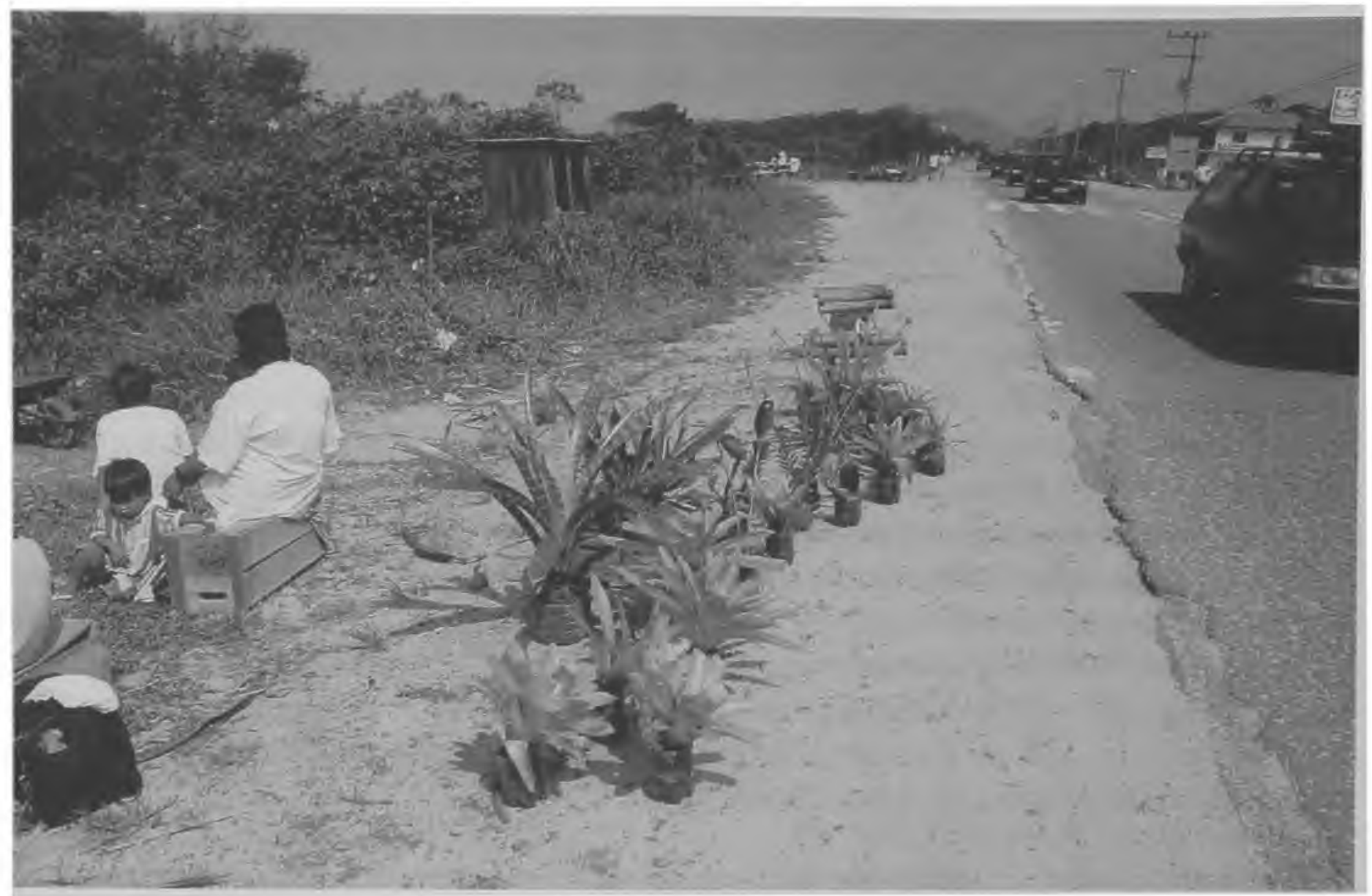

Figura 9: Comércio extrativista de bromélias, na rodovia Rio-Santos, praia de Boracéia, São Sebastião-SP. Bromélia major éV hieroglyphica

Fonte: Foto do autor

Mas ainda há muitas que estão sendo removidas dos ecossistemas naturais, apesar de ser considerado crime o comércio daquelas, e quaisquer outras plantas ou parte delas, oriundas de florestas, sem licença da autoridade competente ${ }^{4}$ As plantas obtidas por extrativismo apresentam-se normalmente com folhas e flores escoriadas, raizes artificialmente fixadas em um substrato e sem procedência de produtor. É comum, por exemplo, encontrał-se $V$. hieroglyphica (espécie ameaçada de extinção no estado de São Paulo, Goldenstein, 1999), $V$. bituminosa, V. gigantea, V. incunvatae Neoregeliasp sendo vendidas no Ceagesp com sinais de terem sido removidas da Mata Atlântica. Da mesma forma encontra-se Aechmea nudicaulis e Nidularium innocentii em arranjos montados sobre troncos de samambaia-açú (Figura 10).

(4) Lei Federal n. 4771/65, artigo 13, para formaçóes floresțais em geral e, para o domínio da Mata Atlântica, o Decreto Federal n. 750/93, artigo 2. 


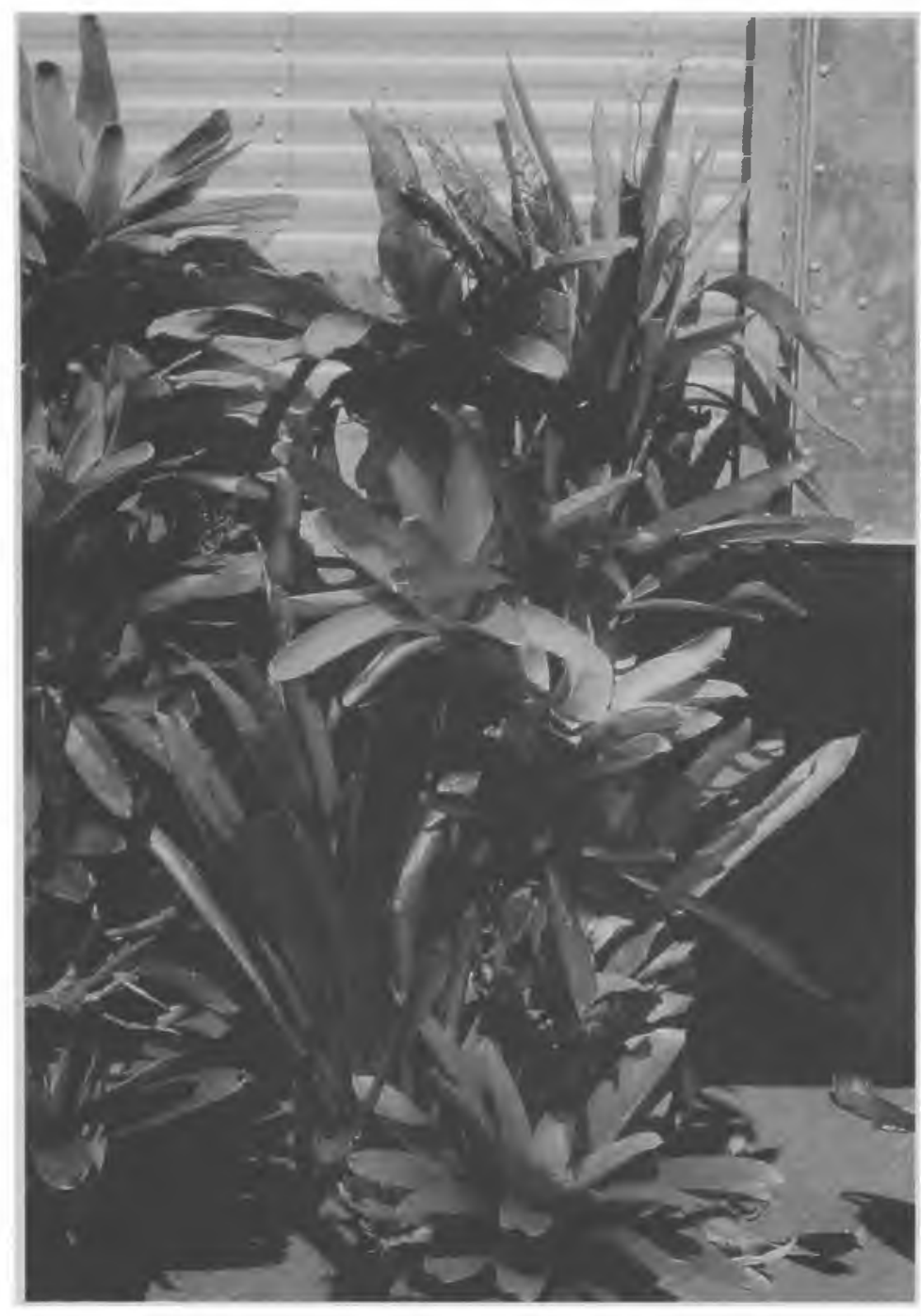

Figura 10: Arranjo de bromélias contendo indivíduos extraídos da mata Fonte: Foto do autor

Também é comum a venda de certas bromélias, retiradas da mata, para turistas na beira de certas rodovias como a SP-055 ou Rio-Santos (São Sebastião-SP) (Figura 9) e BR-101 (Garuva-SC). Na primeira rodovia encontra-se, inclusive, $V$. hieroglyphica sendo vendida.

Provavelmente parte dessas bromélias continuam sendo retiradas de reservas florestais, conforme, por exemplo, o relato de funcionários locais da reserva de Cotia, (Cotia-SP).

Também há o comércio de bromélias não-cisternas, como a Tillandsia usneoides, a conhecida barba-de-velho. Esta espécie, muito pequena e confundida por leigos com o musgo, é vendida em sacos de mais de 50 litros com milhares de indivíduos. É usada para acabamentos em arranjos e vasos ornamentais e já foi usada para preencher o estofamento de banco de carros no começo deste século (Reitz, 1983). Apesar de ainda ser abundante, desconhece-se estudos do impacto de tal extrativismo. Recentemente, outras espécies nativas e ornamentais de Tillandsia podem ser encontradas no Ceagesp, também com sinais de terem sido removidas das matas. Provavelmente o consumo crescente dessa Tillandsia está associado ao modismo do uso de bromélias em geral.

O extrativismo de bromélias para fins ornamentais tem sido apontado como uma das causas determinantes para a extinçāo dessas plantas em ecossistemas naturais (Wanderley, 1999). Assim, por exemplo, entre as medidas conservacionistas propostas para Fernseea itatiaiae, espécie ameaçada de extinção, está a "... criação de programas de educação ambiental... de modo a evitar a coleta de plantas de valor ornamental... " (Mello Filho et al, 1992). O extrativismo para fins ornamentais também é responsável pela drástica diminuição das populações de Vriesia fosteriana (nativa do Espírito Santo) e Vriesia hieroglyphica (Rio de Janeiro e São Paulo) (Leme, 1984). Infelizmente, pouco ou nada se sabe sobre as possíveis conseqüências da extinção dessas espécies. 
A seguir discutem-se propostas legais, educativas, de pesquisa, manejo e projeto de jardim, que podem amenizar ou solucionar os problemas levantados.

\section{Propostas}

Adotando-se a prudência como princípio, apóia-se a diminuição ou proibição do uso de bromélias criadouros de mosquitos em jardins (Estrada-Franco, 1995) até que seja demonstrada, por pesquisa científica, sua inocuidade ao ser humano e aos ecossistemas naturais. Também seria importante intensificar-se a fiscalização quanto à procedência dessas plantas e seu estado fitossanitário e oficializar e atualizar as listas regionais e nacionais de espécies ameaçadas de extinção no Brasil.

Acredita-se, assim como a Sociedade Brasileira de Bromélias (SBBr), 1999, que o extrativismo de bromélias pode diminuir se for aumentada a oferta destas por produção em viveiros. Para tal, sugerem-se incentivos à produção de bromélias não criadouros de mosquitos. Também, estimular a produção e o uso dessas bromélias ameaçadas de extinção são algumas das medidas conservacionistas recomendadas (Mello Filho et al, 1992). Entretanto o estímulo ao uso dessas plantas pode ser "uma faca de dois gumes". já que coletar, em muitos casos é mais barato que produzir: o recente comércio de Tillandsia spp nativas e ornamentais em São Paulo é um exemplo. $O$ estímulo ao uso de qualquer planta nativa deveria vir junto com legislação adequada, fiscalização do comércio e trabalhos de educação. Essas medidas poderiam ser orientadas por entidades como a SBBr, associações de produtores, comerciantes e órgãos de pesquisa.

Por último, deveriam ser desenvolvidos mecanismos de certificação ambiental para todos os produtores de bromélias.

Paralelamente às medidas legais adotadas, necessita-se de uma série de pesquisas com o intuito de entender melhor a relaçāo entre as bromélias de uso ornamental e doenças humanas, para então embasar as medidas legais, modificando-as se necessário. Essas pesquisas deverāo responder, no mínimo, as seguintes questões:

- Quais são as relações entre as várias espécies de bromélias de uso ornamental em jardins, doenças humanas e mosquitos vetores dessas? Como a densidade populacional de cada espécie de bromélia afeta essas relações? Como essas relações variam de acordo com a região, clima e época do ano? Qual o papel das bromélias espontâneas nessas relaçōes e como deve ser o manejo de suas populações?

- Que técnicas e procedimentos poderiam ser usados, tanto na produção quanto nos jardins, para impedir a procriação de mosquitos em bromélias ornamentais?

- Como garantir que a população humana use essas técnicas e procedimentos?

- Qual é o impacto do extrativismo de bromélias para fins ornamentais e como tornar este extrativismo sustentável? 
- Qual é a relação custo-benefício do uso de bromélias em cada regiāo?

Enquanto se espera os resultados dessas pesquisas e a aplicação de medidas legais, pode-se sugerir, além da prudência, algumas medidas que podem minimizar os riscos ao usarem-se essas plantas.

O manejo adequado das bromélias teria como objetivo principal impedir o desenvolvimento das larvas dos mosquitos. A seguir, propõem-se alguns manejos, não-excludentes e semelhantes aos sugeridos por Montegazza et al (1993), para os vários tipos de criadouros de mosquitos:

- Trocar semanalmente a água acumulada entre as folhas;

- Preencher o espaço ocupado pela água entre as folhas com areia ou outro material semelhante;

- Sempre que for necessário adicionar água, fazê-lo sem formar poças;

- Aplicar inseticidas. Recomenda-se o uso deste método em último caso, pois dependendo do tipo, podem causar danos à saúde e ao ambiente. Além disso, sabe-se que as populações de muitas espécies de mosquitos desenvolvem resistência a vários tipos de inseticida (Forattini, 1965a). Por isso são importantes os estudos alternativos de controle populacional das larvas de mosquitos, como o dos ciclopídeos (Crustacea) predadores (Santos \& Andrade, 1997) e das bactérias larvicidas Bacillus thuringiensis (Consoli et al, 1994).

Espera-se que as pesquisas simplifiquem essas sugestōes, pois o aumento e a sofisticação dos serviços de manutenção de jardim é uma desvantagem desses métodos. Talvez por isso, e por falta de divulgação, essas medidas não estejam sendo executadas na maioria dos jardins lobservação do autor em mais de 40 jardins aleatoriamente escolhidos no estado de São Paulo, principalmente na capital). Pior ainda, muitos jardins são irrigados nos meses mais secos do ano, mantendo abundante água entre as folhas das bromélias. Como bem salientou Marques, 1999, em seus estudos em IIha Bela-SP, esse manejo aumenta o período em que essas bromélias servem de criadouro, facilitando a sobrevivência e multiplicação das populações de mosquitos nos períodos mais secos.

Portanto, continua-se dando condições para o aumento das populações destes insetos, pois até o momento, não tem sido adotado um manejo adequado às populaçōes de bromélias no ambiente urbano.

Então, seria mais simples e prudente evitar o uso destas plantas em jardins? Dificilmente podese substituir as formas, cores e texturas das bromélias, cujo uso está sendo questionado. Mas há algumas bromélias que naturalmente não acumulam água suficiente entre as folhas, como 
algumas espécies ornamentais de Bromelia, Dyckia, Pitcairnia, Tillandsia e Vriesia (Veloso, 1958; Mello Filho et al, 1992, Reitz; 1983).

Em alguns casos, uma mudança no projeto do jardim pode ser feita empregando-se plantas que sejam equivalentes ornamentais das bromélias, mas que não sejam criadouros de mosquitos, como o asplênio (Asplenium nidus, Aspleniaceae), babosa-de-pau (Philodendron martianum, Araceae ), abacaxi-roxo (Tradescantia spathacea, Commelinaceae), algumas espécies de pita e sisal (Agave spp, Amaryllidaceae), açucena e curculigo (Crinum spp e Curculigo, Amaryllidaceae), babosa (Aloe spp, Liliaceae).

Mas se essa lista de plantas não agradar, sugere-se dar novo enfoque ao projeto do jardim. Não é possível que entre as centenas de espécies nativas do território brasileiro (um dos mais ricos em espécies do mundo), juntamente com tantas outras espécies introduzidas, não se consiga fazer um jardim mais saudável e que agrade a todos os gostos. Para a busca de alternativas ver, por exemplo, a descrição de mais de mil espécies nativas e exóticas em Lorenzi \& Souza, 1999.

Entretanto, deve-se ter o cuidado em não escolher outras espécies que também acumulem água entre suas folhas ou axilas, pois podem também ser criadouros naturais de mosquitos. Apesar de essas plantas não serem o tema deste artigo, citaremos alguns exemplos: certas espécies de bananeira do mato (Heliconia spp, Musaceae), nepentes (Nepenthes spp, Nepenthaceae), sempre-viva (Eriocaulon sp, Eriocaulaceae) (Lutz, 1950) ou ainda bananeiras (Musa spp, Musaceae), taiobas e afins (Xanthosoma sp, Araceae), espadas-de-são-jorge (Sansevieria spp, Liliaceae), dracenas (Dracaenas spp, Liliaceae) (Haddow, 1948), pandanus (Freycinetia sp, Pandanaceae) e caraguatá (Enyngium sp, Umbelliferae) (Peryassú, 1908). Também é importante citar que os ocos de troncos de árvores e bambus são criadouros em potencial de várias espécies de mosquitos (Forattini, 1965a, 1965b).

Por último, acredita-se que profissionais da área da educação devam ser acionados para a elaboração de cursos de atualização para paisagistas, jardineiros, comerciantes e produtores. Esclarecimentos sobre o tema à população em geral também seria recomendado. Não é raro, por exemplo, encontrar-se cidadãos incapazes de identificar uma larva ou pupa de mosquito e que desconhecem o ciclo de vida destes insetos.

\section{Conclusōes}

O uso das bromélias é um exemplo de como vários projetos paisagísticos, em São Paulo, têm tido um enfoque eminentemente estético, ignorando certos aspectos ecológicos e sanitários fundamentais. As plantas são muito mais que mero ornamentos; elas interagem com o ambiente, muitas vezes de forma complexa. O resultado dessa interação, dependendo da combinação de espécies usadas em determinada área e origem delas, pode não ser favorável à saúde do ser humano e à manutenção de reservas naturais, que são consideradas fundamentais para a sustentabilidade de nossa sociedade. Portanto, normas apoiadas em conhecimento científico devem prevalecer aos modismos do paisagismo. 
As normas municipais que definem o papel das plantas e áreas verdes no ambiente urbano são geralmente precárias. Em vários municípios há apenas a preocupação em impedir o uso de plantas que provoquem danos à fiação e ao calçamento das ruas. Mas há tentativas de melhorá-las: a Agenda 21 Local da cidade de São Paulo é um exemplo (Philippi Jr., 1995). Ela avança a discussão sobre a situação e papel que as áreas verdes têm na sustentabilidade do município, a importância da preservação da biodiversidade, da educação ambiental e da necessidade da manutenção e ampliação das áreas verdes, entre outros assuntos. Entretanto, não aborda se as condutas sanitaristas e funcionais são prioritárias em relação ao aspecto lúdico da paisagem. Não explicita se devemos inibir o consumo de materiais (plantas, seus derivados e insumos agrícolas) que sejam oriundos de um extrativismo não-sustentável. Também há muito a ser definido como prioritário, sobre o que os cidadãos devem saber a respeito de jardins, áreas verdes e ecologia urbana.

Os trabalhos de Lyle (1985) e Franco (1997), por exemplo, mostram a necessidade de uma abordagem multidisciplinar para a elaboração do planejamento de ecossistemas antropomorfizados. A discussão sobre o uso de bromélias em ambientes urbanos reafirma a necessidade da participação de profissionais das áreas da saúde e biológicas, além de arquitetos e engenheiros, como responsáveis na elaboração de leis e projetos, na execução e manutenção de áreas verdes públicas e privadas. Os problemas ambientais não distinguem uma área da outra, os mosquitos também não!

\section{Bibliografia}

ARAGĀO, M. B. Distribuiçāo geográfica e abundância das espécies de Anopheles (Kerteszia) (Díptera, Culicidae). Revista Brasileira de Malariologia e Doenças Tropicais, v. 16, n. 1, p. 73-109, 1964.

CONSOLI, R. A. G. B., LOURENÇO DE OLIVEIRA, R. Principais mosquitos de importância sanitária no Brasil. Rio de Janeiro: FIOCRUZ, 1994. 228p.

CROSSKEY, R. W. Old tools and new taxonomic problems in bloodsucking insects. In: SERVICE, M. W. (ed.). Biosystematics of haematophagous insects. Oxford: Clarendon Press, 1988. p. 1-18. Apud: FORATTINI, O. P. Culicidologia médica, volume 1: Princípios gerais, morfologia, glossário taxonômico. São Paulo, Edusp, 1996. $548 p$.

DEAN, W. A ferro e fogo: A história e a devastação da Mata Atlântica brasileira. Sāo Paulo: Companhia das Letras, 1995. $484 p$.

ESTRADA-FRANCO. J. G. Biology, disease relationship and control of Aedes albopictus. Washington: Pan American Health Organization. 1995.

FERREIRA, M. O. RACHOU, R. G., LIMA, M. M. Consideraçōes sobre o combate ao “Anopheles (Kerteszia) cruzir' em Caldas da Imperatriz (Santa Catarina) pelo desmatamento; abrigos naturais dessa espécie. Revista Brasileira de Malariologia e Doenças Tropicais, v. 3, n. 1, p. 14-35, 1951.

FORATTINI, O. P. Entomologia médica. São Paulo: Faculdade de Higiene e Saúde Pública, 1962. v. 1, 662p. Entomologia médica. Sāo Paulo: Edusp, v. 2, p. 506, 1965 a.

Entomologia médica. São Paulo: Edusp, v. 3, p. 416, 1965.

Aedes (Stegomyia) albopictus (Skuse) identification in Brazil. Revista de Saúde Pública, v. 20, n. 3.

p. $244-5,1986$.

Sāo Paulo n. 13 p. 7395 dez. 2000 
FORATIINI, O. P. Mosquitos culicideos como vetores emergentes de infecções. Revista de Saúde Pública, v. 32, n. 6, p. 497-502, 1999.

FORATTINI, O. P., MARQUES, G. R. A. M., BRITO, M. de. Formas imaturas de anofelíneos em recipientes artificiais. Revista de Saúde Pública, v. 32, n. 2, p. 189-91, 1998.

FORATINI, O. P.; MAROUES, G. R. A. M., KAKITANI, I., BRITO, M. de, SALUM, M. A. M. Significado epidemiológico dos criadouros de Aedes albopictus em bromélias. Revista de Saúde Pública, v. 32, n. 1, p. 186-8, 1999.

FRANK, J. H. Bromeliad - inhabiting mosquitoes in Florida. http://uww.ifas. ufl.edu/ frank/ mosbrom.htm, 1996.

FRANCO, M. A. R. Desenho ambiental: Uma introdução à arquitetura da paisagem com o paradigma ecológico. São Paulo: Annablume, 1997. 224p. il.

GODAS, F. L. Estatísticas do comércio de plantas ornamentais [Comunicação pessoal.] /Chefe de economia e desenvolvimento da Companhia de Entrepostos e Armazéns Gerais do Estado de São Paulo (Ceagesp), 1999.

GOLDENSTEIN, S. (coord.). Espécies da flora ameaçadas de extinção no estado de São Paulo: Lista preliminar. São Paulo (Estado): Secretaria do Estado do Meio Ambiente, 1999. 24p.

GOMES, A. C. Aedes albopictus em área rural do Brasil e implicações na transmissāo de febre amarela silvestre. Revista de Saúde Pública, v. 3, n. 1, p. 95-97, 1999.

HADDOW, A. J. The mosquitoes of Bwamba County, Uganda. VI. Mosquito breeding in plant axils. Bulletin of Entomological Research, v. 39, n. 2, p. 185-212, 1948.

KUMM, H.W. Mosquitoes breeding in bromeliads at Bahia, Brazil. Bulletin of Entomological Research, n. 24. p. 561-573, 1933, pl. 17-18.

LABARTHE, N., Serrao, M. L., Melo, Y. F., Oliveira, S. J., LOURENÇO DE OLIVEIRA, R. Potential vectors of Dirofilaria immitis (Leidy, 1856) in Itacoatira, oceanic region of Niteroi municipality, state of Rio de Janeiro, Brazil. Memórias do Instituto Oswaldo Cruz , v. 93, n. 4, p. 425-432, 1998.

LEME, E. M. C. Bromélias. Ciência Hoje, v. 3, n. 14, p. 67-72, 1984. Bromeliads in the Brazilian wilderness. Rio de Janeiro: Marigo Comunicação Visual, 1993. p. 183.

LORENZI, H., SOUZA, H. M. Plantas ornamentais no Brasil: Arbustivas, herbáceas e trepadeiras. 2. ed. Nova Odessa-SP: Instituto Plantarum. 1999. 1088p., il.

LOURENÇO DE OLIVEIRA, R., HEYDEN, R., SILVA, T. F da. Alguns aspectos da ecologia dos mosquitos (Díptera: Culicidae) de uma área de planície (Granjas Calábria), em Jacarepaguá, Rio de Janeiro. V. Criadouros. Memórias do Instituto Oswaldo Cruz, n. 81, p. 265-272, 1986.

LUTZ, A. Mosquitos da floresta e malária silvestre. Revista Brasileira de Malariologia e Doenças Tropicais, v. 2, n. 2 , p. $91-99,1950$.

LYLE, J. T. Design for human ecosystem's. Nova York: Van Nostrand Reinhold, 1985. 279p.

MANTOVANI, W. A vegetação sobre a restinga de Caraguatatuba, SP. Revista do Instituto Florestal, ed. esp. v. 4. n. 1, p. 139-144, 1992.

MARQUES, G. Manejo de bromélias em jardins [Comunicação pessoal] (Pós-graduanda da Faculdade de Saúde Pública da Universidade de São Paulol. 1999.

MELlO FIlHO, L. E. de, SOMNER, G. V., PEIXOTO, A. L. (coord.) Centuria Plantarun Brasiliensium Exstintionis Minitata. Sociedade Botânica do Brasil, 1992. 167p.

MONTEGAZZA, E., GLASSER, C. M., CHEQUER, D. C., ALVES, M. J. C. P. Manual de atividades para controle dos vetores de dengue e febre amarela - Controle mecânico e químico. São Paulo: Sucen, Governo do Estado de São Paulo. 1993.

MOTTA, F. L. Roberto Burle Marx e a nova visão de paisagem. São Paulo: Nobel, 1983. 255p. il.

NATAL, D. Encontro de Aedes (Stegomyia) albopictus (Skuse) em Bromeliaceae na periferia de São Paulo, SP, Brasil. Revista de Saúde Pública, v. 31, n. 5, p. 517-8, 1997.

\begin{tabular}{l|l}
94 & Paisagem \\
Ambiente \\
Ensaios \\
13
\end{tabular}

Sāo Paulo n. 13 p. 7395 dez. 2000 
O'MEARA, G. F., Gettman, A. D., EVANS JR., L. F., CURTIR, G. A. The spread of Aedes albopictus in Florida. American Entomologist, n. 39, p. 163-72, 1993.

PERYASSÚ, A. G. Os culicideos do Brazll. Rio de Janeiro: Instituto de Manguinhos, 1908. 407p. il.

PHILIPPI JR., A. (coord.). Agenda 21 Local: Compromisso da cidade de São Paulo. São Paulo: Secretaria do Verde e do Meio Ambiente, 1995. 165p.

PINOTTI, M. O problema de malária transmitida por Kerteszia no Sul do Brasil. Revista Bras/leira de Malariologia, v. 1, n. I, p. 2-3, 1949.

PITTENDRIGH, C. S. Bromeliad malaria in Trinidad, B.W.I. American Journal of Tropical Medicine and Hygiene, v. 26, n. 1, p. $47-66,1946$. p. 58-89, 1948 .

The bromeliad-Anopheles-malaria complex in Trinidad. I. The bromeliad flora. Evolution, v. 2, n. 1 ,

REITZ, R. Bromeliáceas e a malária-bromélia endêmica. Flora llustrada Catarinense, n. 1, p. 1-808, 1983.

Bromélias na trama da malária. Ciência Hoje, v. 4, n. 21, p. 50-57, 1985.

RIOS A., R, KHAN, B. List of ethnobotanical use of Bromeliaceae. Journal of Bromeliad Society, v. 48, n. 2, p. 7587, 1998

SANTOS, L. U., ANDRADE, C. F. Levantamento de ciclopídeos (Crustácea, Copepoda) no Brasil e avaliação preliminar de seu potencial como predadores dos vetores da dengue. Revista de Saúde Pública, v. $31, n .3$. p. $221-226,1997$

SOBRAL, R. H. 1996. O meio ambiente e a cidade de São Paulo. São Paulo: Makron Books. 80 p., il.

SOCIEDADE BRASILEIRA DE BROMÉLIAS. Apresentaçāo. http://www.bromelia.org.br/Apres.htm, 1999.

SPIRN, A. W. The granite garden. Nova York: Basic Books, 1984. 345p. il.

VELOSO, H. P Consideraçōes gerais sobre os biótopos e hábitats dos anofelíneos do subgênero Kerteszia. Memórias do Instituto Oswaldo Cruz, v. 56, n. 1. p. 163-179, 1958.

VELOSO, H. P, F.ONTANA, J. P. KLEIN, R. M., SIOUEIRA-JACCOUD, R. J. de. Os anofelinos do subgênero Kerteszia em relação à distribuição das bromeliáceas em comunidades florestais do município de Brusque, Estado de Santa Catarina. Memórias do Instituto Oswaldo Cruz, v. 54, n. 1, p. 1-86, $1956 a$.

VELOSO, H. P., MOURA, J. V. de, KLEIN, R. M. Delimitaçāo ecológica dos anofelínoes do subgênero Kerteszia na regiāo costeira do Sul do Brasil. Memórias do Instituto Oswaldo Cruz, v. 54, n. 1, p. 517-534, 1956b.

WANDERLEY, M. G. L. Espécies vegetais ameaçadas de extinção [Comunicação pessoal] (Pesquisadora do Instituto de Botânica - Secretaria do Meio Ambiente do Estado de São Paulo (SMA/SP), 1999 